\title{
Application of Taguchi Method-Moldflow-Particle Swarm Optimization for Plastic Injection Process Parameters Optimization
}

Sigit Yoewono Martowibowo ${ }^{1}$, Agung Kaswadi ${ }^{2}$, Gita Suryani Lubis ${ }^{3}$

${ }^{1}$ Faculty of Mechanical and Aerospace Engineering, Institut Teknologi Bandung. Jalan Ganesa 10. Bandung 40132. Indonesia. E-mail: sigit@ftmd.itb.ac.id

${ }^{2}$ Politeknik Manufaktur Astra. Jalan Gaya Motor Raya No 8. Jakarta 14330. Indonesia. E-mail: agung.kaswadi@polman.astra.ac.id

${ }^{3}$ Faculty of Engineering, Tanjungpura University, Jalan Prof. Hadari Nawawi. Pontianak. Kalimantan Barat 78124. Indonesia.

Plastic injection process is one of the techniques used to manufacture plastic products. The technique is widely used due to its higher and faster production capacity and low cost. However, production process problems are often found, one of which is inappropriate process parameters settings, which may cause product defects. This paper presents a method using combination of Taguchi method, Moldflow simulation and PSO to optimize plastic injection molding process parameters. Moldflow simulations were run to obtain volumetric shrinkage values resulting from each combination of parameters setting selected by means of OA. In adopting $\mathrm{S} / \mathrm{N}$ ratio technique of the Taguchi method, the study adhered to the principle of "the smaller the better". The ANOVA method was also used to analyze the effect of each process parameter on volumetric shrinkage and a regression analysis was used to establish the equation used for the application of the PSO method to optimize plastic injection process parameters. This method was applied for the production of number plate brackets from PP AZ564 material. The study concluded that the application of the combined Taguchi-Moldflow-PSO method could reduce volumetric shrinkage from $6.05 \%$ to $4.24 \%$.

Keywords: Plastic Injection Process, Taguchi Method, PSO, Moldflow Simulation, Volumetric Shrinkage

\section{Acknowledgement}

The authors would like to express their gratitude to the Ministry of Research, Technology and Higher Education of the Republic of Indonesia, for their financial assistance to this study. The authors also thank to the Politeknik Manufaktur Astra, Indonesia, for their provision of laboratory facilities.

\section{References}

[1] ANDRISANO, A.O., GHERARDINI, F., LEALI, F., PELliCCIARI, M., VERGNANO, A. (2011). Design of simulation experiments method for injection molding process optimization. In: Proceeding of the International Conference on Innovative Methods in Product Design, 15-17 June 2011, pp. 476-486, Venice, Italy.

[2] CHEN, W.S., YU, F.J., WU, S.H. (2011). A Robust design for plastic injection molding applying Taguchi method and PCA. In: Journal of Science and Engineering Technology, Vol. 7, No. 2, pp. 1-8. Taiwan.

[3] FARSHI, B., GHESHMI, S., MIANDOABCHI, E. (2011). Optimization of injection molding process parameters using sequential simplex algorithm. In: Materials \& Design, Vol. 32, No. 1, pp. 414-423. Elsevier BV. Netherlands.

[4] GONDÁR, E., SCHREK, A., ŠVEC, P. (2016). Reduction of sink marks in injection overmolding process of metal-plastic parts. In: Manufacturing Technology, Vol.16, No. 6, pp. 1259-1264. Institute of Technology and Production Management University of J.E. Purkyne. Czech Republic.

[5] HUANG, M.C., TAI, C.C. (2001). The effective factors in the warpage problem of an injection-molded part with a thin shell feature. In: Journal of Materials Processing Technology, Vol. 110, No. 1, pp. 1-9. Elsevier BV. Netherlands.

[6] HUBA, J., SANETRNIK, D., HNATKOVA, E., HAUSNEROVA, B., DVORAK, Z. (2016). New application of powder injection molded product in medical field. In: Manufacturing Technology, Vol.16, No. 1, pp. 94-98. Institute of Technology and Production Management University of J.E. Purkyne. Czech Republic.

[7] HUSSIN, R., MOHD SAAD, R., HUSSIN, R., MOHD DAWI, M.S.I. (2012). An optimization of plastic injection molding parameters using Taguchi optimization method. In: Asian Transactions on Engineering, Vol. 2, No. 5, pp. 75-80. Asian Transactions. Pakistan. 
[8] KAMARUDDIN, S., KHAN, Z.A., FOONG, S.H. (2010). Application of Taguchi method in the optimization of injection moulding parameters for manufacturing products from plastic blend. In: IACSIT Int. J. Eng. and Technol., Vol. 2, No. 6, pp. 574-580.

[9] KENNEDY, J., EBERHART, R.C. (1995). Particle swarm optimization. In: Proceedings of the 1995 IEEE International Conference on Neural Networks, pp. 1942-1948. IEEE Service Center, Perth, Australia.

[10] MARTOWIBOWO, S.Y., WAHYUDI, A. (2012). Taguchi method implementation in taper motion wire EDM process optimization. In: Journal of The Institution of Engineers (India): Series C, Vol. 93, No. 4, pp. 357-364. Institution of Engineers. India.

[11] MONKA, P., HLOCH, S., ANDREJ, A., SOMSAK, M., MURGAS, F. (2016). Simulation tools used at the injection mould design. In: Manufacturing Technology, Vol.16, No. 3, pp. 561-569. Institute of Technology and Production Management University of J.E. Purkyne. Czech Republic.

[12] PARK, H.S., NGUYEN, T.T. (2014). Optimization of injection molding process for car fender in consideration of energy efficiency and product quality. In: Journal of Computational Design and Engineering, Vol. 1, No. 4, pp. 256-265. Elsevier BV. Netherlands.

[13] ROSATO, D.V., ROSATO, D.V., ROSATO, M.G. (2000). Injection Molding Handbook (3rd ed.). Kluwer Academic Publishers, Massachusetts.

[14] SPINA, R. (2006). Optimisation of injection moulded parts by using ANN-PSO approach. In: Journal of Achievements in Material and Manufacturing Engineering, Vol. 15, No. 1-2, pp. 146-152. Polish Academy of Sciences. Poland.

[15] TAGUCHI, G. (1990). Introduction of Quality Engineering. Asian Productivity Organization, Mc Graw-Hill, New York.

[16] VAATAINEN, O., PENTTI, J. (1994). Effect of processing parameters on the quality of injection moulded parts by using the Taguchi parameter design method. Plastics, Rubber and Composites, Vol. 21, pp. 2117. Maney Publishing. United Kingdom.

[17] XU, G., DENG, F.B., XU, Y.H. (2011). Adaptive particle swarm optimization-based neural network in quality prediction for plastic injection molding. Journal of Computational Information Systems, Vol. 7, No. 2, pp. 462470. Binary Information Press. USA.

[18] ZHOU, H. (2013). Computer Modeling for Injection Molding: Simulation, Optimization, and Control, pp. 8 \& 38. John Wiley \& Sons, Inc., New Jersey. 